\title{
Consequences of dike breaches and dike overflow in a bifurcating river system
}

\author{
Anouk Bomers $^{1}$ (D) . Ralph M. J. Schielen ${ }^{1,2} \cdot$ Suzanne J. M. H. Hulscher ${ }^{1}$
}

Received: 11 October 2018 / Accepted: 13 June 2019 / Published online: 17 June 2019

(c) The Author(s) 2019

\begin{abstract}
Currently, the effect of dike breaches on downstream discharge partitioning and flood risk is not addressed in flood safety assessments. In a bifurcating river system, a dike breach may cause overland flows which can change downstream flood risk and discharge partitioning. This study examines how dike breaches and overflow affect overland flow patterns and discharges of the rivers of the Rhine delta. For extreme discharges, an increase in flood risk along the river branch with the smallest discharge capacity was found, while flood risk along the other river branches was reduced. Therefore, dike breaches and resulting overland flow patterns must be included in flood safety assessments.
\end{abstract}

Keywords Dike breaches · Discharge partitioning $\cdot$ Hydraulic flood modelling · Overland flow $\cdot$ Flood risk

\section{Introduction}

Throughout Europe, flood frequency analyses are widely used to estimate discharges associated with various return periods (Benito et al. 2004). The common procedure of a flood frequency analysis is to select the annual extreme discharges of the observational data, or peak values that exceed a certain threshold (Hegnauer et al. 2014). These extreme values are then used to identify the parameters of a probability distribution that provides statistical data about the selected extreme values. From this fitted distribution, discharges corresponding to any return period can be derived (Hegnauer et al. 2014).

However, a major drawback of the flood frequency analysis is that the effects of inundations as a result of upstream overflow and dike breaches on the downstream discharge wave cannot be incorporated in the analysis unless such events have occurred during the measurement period. In the case of a single branch river system, a dike breach results in a decrease of the maximum discharge further downstream and hence in a reduction in the hydraulic load downstream (De Bruijn et al. 2014; Schweckendiek et al. 2008; Vorogushyn et al. 2010) if the water does not flow back into the river at a

Anouk Bomers

a.bomers@utwente.nl

1 University of Twente, Dienstweg 1, Enschede, The Netherlands

2 Ministry of Infrastructure and Water Management-Rijkswaterstaat, Arnhem, The Netherlands 
downstream location. For all river systems, dike breaches can result in serious flooding. However, a dike breach in a river system with multiple bifurcations can result in a change of the discharge partitioning of these bifurcations since water may flow through the embanked areas towards another river or river branch. This may specifically result in a change in flood risk if the discharge capacity of the other river is much lower than the capacity of the river in which the dike breach occurred. This situation is applicable in every region where two or more rivers are situated close to each other and where the natural terrain allows that a part of the discharge that leaves a specific river system flows towards another river branch. Such inundation patterns are possible in almost any deltaic areas (e.g. Lower Mississippi river and Atchafalaya river (Coleman et al. 1998), the Mekong delta (Triet et al. 2017) and the Rhine delta (Bomers et al. 2018; Klerk et al. 2014)).

Excluding overland flows from flood frequency analysis results in an inaccurate prediction of design discharges since overland flows may alter downstream discharge partitioning. In recent years, awarenesses of the effects of dike breaches, resultant inundations and hence potential changes in downstream flood risk has increased. Apel et al. (2009) studied the effects of dike breaches on downstream flood peak reductions for the Lower Rhine in Germany. They developed a dynamic-probabilistic model that combines simplified flood process modules in a Monte Carlo simulation framework. In their study area, no bifurcation points were present. Apel et al. (2009) showed that for extreme floods, significant retention effects are expected as a result of dike breaches. These retention effects lead to a reduction in the maximum discharge downstream of the dike breach and hence result in a changed flood frequency curve. A similar approach was used by Vorogushyn et al. (2010) who ran a Monte Carlo simulation in which the uncertainty of parameters that influence the breaching process was accounted for by treating them as random variables. They used the Elbe river in Germany as their case study and created hazards maps showing the most vulnerable regions in terms of inundation. Although Apel et al. (2009) and Vorogushyn et al. (2010) included the capping effect of dike breaches, they assumed that once a part of the discharge wave left the river system, it was not capable of flowing back into the river at a downstream location. Furthermore, they did not include the backwater effects caused by downstream dike breaches. However, overland flow patterns may alter the discharge partitioning of downstream river branches and flood risk, whereas backwater effects may increase the maximum discharge upstream of the dike breach location. Therefore, the objective of this paper is to study the effect of overland flow patterns on downstream discharge partitioning and flood risk capturing the full dynamics of a river delta (therefore including all possible flow patterns due to multiple dike breaches and backwater effects). The method proposed by Apel et al. (2009) is used as a starting point and extended such that overland flow patterns and backwater effects are included in the model approach. The upstream part of the Rhine delta is used as a case study to apply the proposed methodology. A large number of potential flood scenarios are simulated in a Monte Carlo framework. The model results are compared with the method proposed by Apel et al. (2009) to determine whether overland flows and backwater effects can change inundation patterns and peak discharges in a river delta.

Firstly, the Rhine delta and its flow regime are described in Sect. 2. Section 3 presents the hydraulic model used. The methodology of the Monte Carlo analysis is explained in Sect. 4, and the results are presented in Sect. 5. The results of the sensitivity analysis are provided in Sect. 6. The paper ends with a discussion and the main conclusions in Sect. 7. 


\section{Study area}

The Rhine delta is used as a case study. The Rhine river originates in the Alps in Switzerland and flows through Germany where the flood-prone area widens until it becomes a river delta in the Netherlands (Hooijer et al. 2004). The study area stretches from Andernach, Germany, to the Dutch Rhine river branches (Fig. 1). Only the dischargedominated upper part of the Dutch Rhine river branches is included in the domain. The downstream part that is influenced by the tide of the North Sea is not included to decrease model complexity.

The German part of the river is referred to as the Lower Rhine. Along the Lower Rhine, three major tributaries are present: the Sieg, Ruhr and Lippe rivers. Their discharges contribute to the peak discharge of the Lower Rhine. In the upstream region, between the upstream boundary condition and the confluence with the river Sieg, no embanked areas are present in the model domain. In this region, inundations of the embanked areas are not possible to occur since the river is surrounded by higher ground on both sides. The Lower Rhine enters the Netherlands at Lobith, where it bifurcates

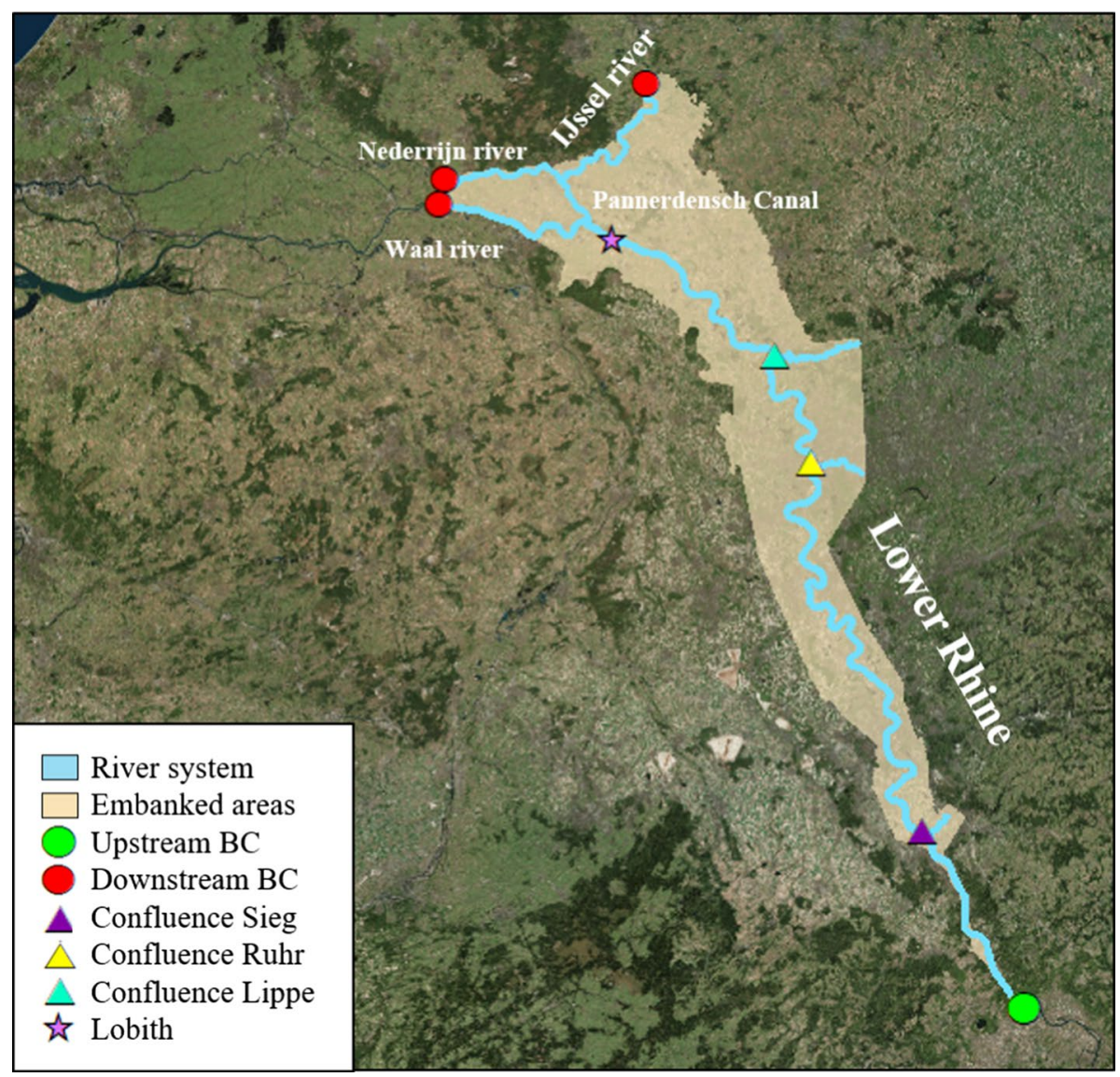

Fig. 1 Representation of the model domain in which Lobith represents the German-Dutch border and BC represents the boundary conditions 
into the Waal river and the Pannerdensch Canal. Subsequently, the Pannerdensch Canal bifurcates into two branches: the Nederrijn river and the IJssel river.

Floods along the Lower Rhine in Germany mainly evolve during the winter months due to heavy precipitation events in combination with frozen or saturated soil. In the annual maximum discharge series for the previous 120 years, $85 \%$ of the annual maxima took place between November and March (Apel et al. 2009). All river branches are almost completely protected by dikes in order to protect the hinterland from flooding. The safety levels along the Lower Rhine vary between a return period of 100 to 500 years for the large winter dikes (ICPR 2001). In 2050, the main levees along the Dutch Rhine river branches need to have a safety standard expressed in probability of flooding up to $10^{-5}$. These probabilities are based on a risk-based analysis. In this analysis, not only the probability of a flood is considered but also the predicted consequences (Van Alphen 2016). In our study, we focus on the actual failure probabilities since many dike sections do not cope with the future safety standard yet (Fig. 2). The differences in the current dike failure probabilities (Fig. 2) may lead to a situation of a dike breach at a relatively weak spot. Resulting overland flows may change the flood risk and discharge partitioning along the downstream river branches.

Currently, the Dutch water policy assumes a fixed discharge partitioning along the various Rhine river branches at extreme discharges. It is assumed that of the total discharge at Lobith approximately $65 \%$ flows to the Waal river, $19 \%$ to the Nederrijn river and $16 \%$ to the IJssel river (Spruyt and Asselman 2017). In the new risk-based approach, the flood event with a return period of 100,000 years has a maximum discharge below $18,000 \mathrm{~m}^{3} / \mathrm{s}$ at Lobith (Hegnauer et al. 2014). The analysis of Hegnauer et al. (2014) shows that this discharge cannot become larger as a consequence of overflow and dike breaches along the Lower Rhine. Using the predefined discharge partitioning means that theoretically a maximum discharge of approximately $11,775 \mathrm{~m}^{3} / \mathrm{s}$ can flow towards the Waal river, around $3376 \mathrm{~m}^{3} / \mathrm{s}$ towards the Nederrijn river and only around $2850 \mathrm{~m}^{3} / \mathrm{s}$ towards the IJssel river at maximum (Spruyt and Asselman 2017).

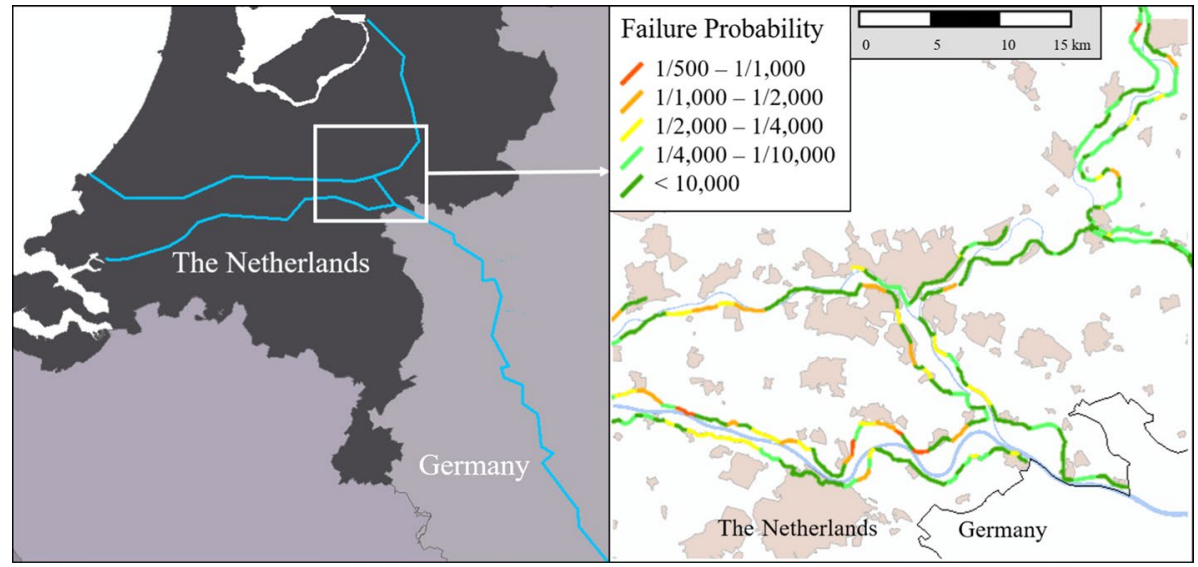

Fig. 2 Current failure probabilities of the Dutch dike sections Source: Ministry of Infrastructure and Water Management (retrieved from https://professional.basisinformatie-overstromingen.nl/liwo/\#/viewer/41, in Dutch) 
To study if overland flow patterns may change this discharge partitioning and corresponding flood risk in the Rhine delta, a hydraulic model is required. This model is described in the next section.

\section{Model environment}

A one-dimensional-two-dimensional (1D-2D) coupled hydraulic model is developed in order to simulate the discharge propagation from Andernach, Germany, to the Dutch deltaic area (Fig. 1). HEC-RAS (v. 5.0.3), developed by the Hydrologic Engineering Centre (HEC) of the US Army Corps of Engineers is used to perform the simulations. Andernach is used as upstream boundary location since it has a measurement station and is situated in the narrow valley of the Middle Rhine. In our modelling approach, the main channel and floodplains are discretized by 1D profiles representing the cross sections of the river. These 1D profiles are coupled with the embanked areas (located outside the protection of the dike system) which are discretized on a 2D grid since 1D profiles are not capable of capturing the complex hydrodynamic conditions inside these areas (Fig. 3). The 2D grid is aligned with line segments with higher grounds such as elevated highways to sufficiently capture the characteristics of the DEM. In most part of the model domain, rectangular grid cells are used, where only flexible grid shapes (e.g. triangular, rectangular, pentagonal cells) are located along the boundaries and line segments such that the $2 \mathrm{D}$ grid is capable of following the boundaries of the model domain and higher grounds (Fig. 3).

The 1D profiles and 2D grid cells are coupled by a structure corresponding with the dimensions of the dike that protects the hinterland from flooding. If the computed water level of a 1D profile exceeds the dike crest, water starts to flow into the 2D grid cells corresponding with inundations of the embanked areas.

HEC-RAS is capable of solving the Full Momentum equations as well as the diffusive wave equations in which the inertial terms of the momentum equations are neglected. Test runs with both sets of equations were performed. Both runs provided almost the same results, as was also found by Moya Quiroga et al. (2016). The maximum discharge at Lobith deviated only $0.3 \%$, and also no significant deviation in flood extent was found. However, the computation time of the run solving the diffusive wave equations was significantly faster. Therefore, the diffusive wave equations are used to compute the flow characteristics (e.g. water level, flow velocity) at each 1D-profile and 2D grid cell.

As upstream boundary condition, a discharge wave is used. Besides the upstream discharge wave, also the hydrographs of the three main tributaries influence the maximum discharge along the Lower Rhine. Therefore, the hydrographs of the tributaries are included in the model approach as lateral inflows (Fig. 1). Normal depths are used as downstream boundary conditions. Normal depths are computed with the use of the Manning's equation which can be written as (Brunner 2016):

$$
V=\frac{R^{2 / 3}}{n} \sqrt{S_{f}}
$$

in which $V$ represents the cross-sectional averaged flow velocity $[\mathrm{m} / \mathrm{s}], \mathrm{R}$ the hydraulic radius $[\mathrm{m}]$ depending on the water depth, $\mathrm{n}$ the Manning's roughness coefficient $\left[\mathrm{s} / \mathrm{m}^{1 / 3}\right]$, and $S_{f}$ the slope of the energy grade line [-]. Since the flow velocity is known, the Manning's equation with a user-entered energy slope produces a water depth considered to be the normal depth as the hydraulic radius is the only unknown in the Manning's equation. In 


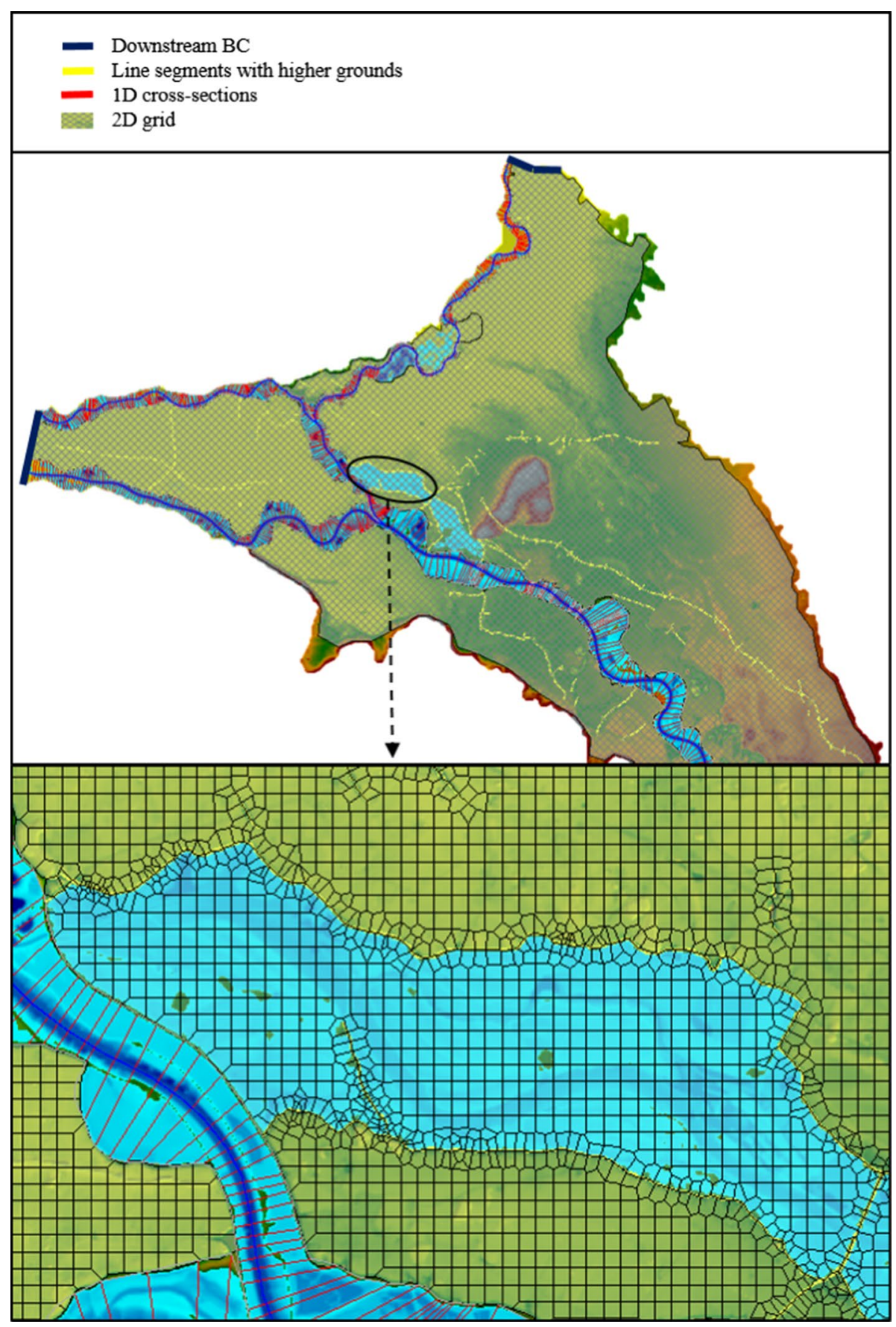

Fig. 3 Model set-up where BC represents the boundary condition (upper figure) and an impression of a part of the 2D grid which is aligned with line segments with high grounds (lower figure) 
general, the energy slope can be approximated by the slope of the main channel (Brunner 2016). This approximation is used to determine the downstream boundary conditions along the three Dutch river branches and downstream ends of the 2D grids (Fig. 3).

For dike breach modelling, the built-in time growth template in HEC-RAS is used in which an S-function is assumed such that the dike breach width increases slowly at first and then accelerates as time advances, and finally slows down again when the breach is almost fully developed (Gee 2010). Prediction of dike breach growth is highly uncertain and many models exist. However, Brunner (2014) showed that overland flows are not sensitive to the dike breach model used. He found that the use of different breach models resulted in a different outflow hydrograph, but once the hydrographs are routed downstream through the embanked areas, the hydrographs will tend to converge to each other and become very similar. There are two main reasons for this convergence. Firstly, the total volume of water in each of the different hydrographs predicted by the different breach models was more or less the same. Secondly, as the hydrographs move through the embanked areas, a sharp hydrograph attenuates faster than a flat hydrograph as a result of bed roughness (Brunner 2014). The above finding justifies the use of the simple built-in time growth template in HEC-RAS since we are not interested in correct prediction of the outflow hydrographs at breach locations, but in the large-scale overland flow patterns. Although the breach model used does not significantly change model results, the input parameters (dike breach threshold, formation time and final breach width) of these models are uncertain and may affect the overland flow patterns. Therefore, these input parameters are considered as random input variables in the Monte Carlo analysis (Sect. 4).

An existing data set of the 2025 geometry is provided by the Dutch Ministry of Infrastructure and Water Management and the Landesamt für Natur, Umwelt und Verbraucherschutz (LANUV) of Northrhine-Westfalia for use in this project. This data set contains a DEM, roughness information and the location and height of the dikes of the present situation in the Netherlands and Germany. The data covers the entire study area except for the embanked area enclosed by the Waal river, Pannerdensch Canal and Nederrijn river (Fig. 1). This latter area is reconstructed with the use of open-source data AHN (Algemeen Hoogtekaart Nederland) available at http://www.ahn.nl/ which represents the Dutch DEM in high-resolution $(5 \times 5 \mathrm{~m})$ raster format. OpenStreetMap (https://www.openstreetmap. org) is used to schematize the roughness classes of this area. Only the five most dominant roughness classes are considered resulting in an almost entirely covered land classification map. The five roughness classes considered are: urban areas, grasslands, alluvial forest, orchard and open surface water. In essence, the 2025 geometry corresponds with the 2015 situation. Because of the ongoing dike reinforcements along the Lower Rhine, only the German dike locations and heights are based on the future 2025 situation. Therefore, data representing the 2015 situation can be applied in the modelling framework.

The model is calibrated such that measured water levels are accurately predicted. Hydraulic model calibration is most commonly done by changing the roughness of the main channel until simulated water levels are close to measured water levels (Bomers et al. 2019b). In this study, the same approach was used with the criterion that the calibration must lead to a maximum difference between measured and simulated water levels of $10 \mathrm{~cm}$. The model is calibrated with the 1995 flood wave data. This flood event had a maximum discharge at Andernach of $10,100 \mathrm{~m}^{3} / \mathrm{s}$. This discharge in combination with the discharge waves of the tributaries along the Lower Rhine resulted in a maximum discharge of around 12,060 $\mathrm{m}^{3} / \mathrm{s}$ at Lobith, corresponding with a return period of approximately 60 years (Tijssen 2009). After calibration, maximum water levels are predicted with an average difference of $1 \mathrm{~cm}$ compared to measurements (Table 1). The 
Table 1 Calibration and validation water level (WL) results with the 1995 and 1993 flood wave, respectively. Diff. represents the differences between measured and simulated WL

\begin{tabular}{lllrllr}
\hline Location & $\begin{array}{l}\text { Measured } \\
\text { WL 1995 (m } \\
\text { + NAP) }\end{array}$ & $\begin{array}{l}\text { Simulated } \\
\text { WL 1995 }(\mathrm{m} \\
\text { + NAP) }\end{array}$ & $\begin{array}{l}\text { Diff. (m) } \\
\text { Measured } \\
\text { WL 1993 (m } \\
\text { + NAP) }\end{array}$ & $\begin{array}{l}\text { Simulated } \\
\text { WL 1933 (m } \\
\text { + NAP) }\end{array}$ & Diff. (m) \\
\hline Andernach & 61.77 & 61.76 & -0.01 & 61.98 & 61.87 & -0.11 \\
Bonn & 52.76 & 52.77 & 0.01 & 52.79 & 52.81 & 0.02 \\
Cologne & 45.67 & 45.69 & 0.02 & 45.60 & 45.69 & 0.09 \\
Ruhrort & 27.79 & 27.78 & -0.01 & 27.51 & 27.56 & 0.05 \\
Wesel & 22.42 & 22.43 & 0.01 & 22.14 & 22.24 & 0.10 \\
Rees & 19.33 & 19.33 & 0.00 & 19.03 & 19.13 & 0.10 \\
Emmerich & 17.84 & 17.84 & 0.00 & 17.52 & 17.64 & 0.12 \\
Lobith & 16.66 & 16.67 & 0.01 & 16.39 & 16.49 & 0.10 \\
Pannerdensche & 15.84 & 15.85 & 0.01 & 15.58 & 15.68 & 0.10 \\
$\quad$ Kop & & & & & & \\
Nijmegenhaven & 13.53 & 13.54 & 0.01 & 13.35 & 13.38 & 0.03 \\
Ijsselkop & 13.98 & 13.99 & 0.01 & 13.77 & 13.85 & 0.08 \\
Driel Boven & 11.97 & 11.94 & -0.03 & 11.73 & 11.74 & 0.01 \\
Driel Beneden & 11.88 & 11.88 & 0.00 & 11.66 & 11.67 & 0.01 \\
Doesburgbrug & 10.59 & 10.59 & 0.00 & 10.43 & 10.41 & -0.02 \\
Average & & & 0.01 & & & 0.07 \\
\hline
\end{tabular}

Dutch water levels are available at http://waterinfo.rws.nl and provided by the Dutch Ministry of Infrastructure and Water Management, whereas the German water levels are available at the German Federal Waterways and Shipping Administration (WSV) and communicated by the German Federal Institute of Hydrology (BfG).

The 1993 discharge wave with a maximum discharge of $10,500 \mathrm{~m}^{3} / \mathrm{s}$ at Andernach is routed for validation. This discharge wave resulted in a maximum discharge of around $11,100 \mathrm{~m}^{3} / \mathrm{s}$ at Lobith as a result of the lower inflow of the tributaries along the Lower Rhine compared to the 1995 flood event. The 1993 flood event at Lobith has a return period of approximately 30 years (Tijssen 2009). It was found that simulated maximum water levels deviate less than $7 \mathrm{~cm}$ averaged over the 14 measurement stations compared to measured maximum water levels during the 1993 flood event (Table 1). Furthermore, the maximum discharges along the Rhine river branches are predicted with high accuracy. The maximum deviation was found along the Waal river, where the simulated maximum discharge differs only $3.7 \%$ from measurements (Table 2). These results give confidence in the accuracy of the model. Both the 1993 and 1995 discharge waves did not lead to any dike breaches in the study area, and hence no overland flows were present. Therefore, it is not possible to validate the model for such situations. However, many studies showed the applicability of a 1D-2D coupled model (e.g. Bomers et al. 2019a; Domeneghetti et al. 2013) and of the diffusive wave equations for flood modelling purposes (e.g. Moya Quiroga et al. 2016; Moussa and Bocquillon 2009; Leandro et al. 2014). Therefore, it is assumed that this model is also capable of simulating large overland flows as a result of overflow and dike breaches with sufficient accuracy. 
Table 2 Calibration and validation results of the discharge (Q) partitioning along the Dutch Rhine river branches with the 1995 and 1993 flood waves, respectively. Diff. represents the differences between measurements and model predictions

\begin{tabular}{lccrcrr}
\hline River branch & $\begin{array}{l}\text { Measured Q } \\
1995\left(\mathrm{~m}^{3} / \mathrm{s}\right)\end{array}$ & $\begin{array}{l}\text { Simulated Q } \\
1995\left(\mathrm{~m}^{3} / \mathrm{s}\right)\end{array}$ & Diff. (\%) & $\begin{array}{l}\text { Measured Q } \\
1993\left(\mathrm{~m}^{3} / \mathrm{s}\right)\end{array}$ & $\begin{array}{l}\text { Simulated Q } \\
1933\left(\mathrm{~m}^{3} / \mathrm{s}\right)\end{array}$ & Diff. (\%) \\
\hline Bovenrijn & 11,878 & 12,018 & 1.2 & 11,093 & 11,420 & 2.9 \\
Waal & 7587 & 7719 & 1.7 & 7112 & 7372 & 3.7 \\
Pannerdensch Canal & 4291 & 4300 & 0.2 & 3982 & 4051 & 1.7 \\
Nederrijn & 2513 & 2531 & 0.7 & 2336 & 2421 & 3.6 \\
IJssel & 1780 & 1765 & -0.9 & 1643 & 1624 & -1.2 \\
\hline
\end{tabular}

\section{Monte Carlo analysis}

To determine the influence of dike breaches on downstream discharges and flood risk, we use a Monte Carlo analysis. It is assumed that dike breaches can only occur along the river branches downstream of the confluence with the Lippe river since dike breaches further upstream will not influence the discharge partitioning of the Dutch river branches. Upstream of this location, only the capping effect of high discharges is included as a result of overflow. Hence, is assumed that the dikes have an infinite strength (i.e. will never breach).

In total, 33 dike breach locations are implemented in the model (Fig. 4). These locations are based on a run in which all dikes were removed from the geometry. A reasonable large discharge wave (i.e. larger than bankfull) selected from the historical measured series was released to identify the locations where water may leave the river system resulting in overland flow. In addition, the locations where the overland flow may re-enter the river system were identified. In this way, the dike breach locations that will result in great overland flows, and hence may change the downstream discharge partitioning, were identified.

In the analysis, only the parameters that influence dike breach outflow are included as uncertain input parameters. Following the method of Apel et al. (2009) and Vorogushyn et al. (2010), these parameters are:

- Upstream flood wave in terms of hydrograph shape and peak value

- Flood waves of the main tributaries dependent on the upstream flood wave

- Dike breach threshold in terms of critical water level (based on fragility curves) indicating when the dike starts to breach

- Dike breach formation time

- Final breach width

For each Monte Carlo simulation, an upstream discharge wave and corresponding discharge waves of the three main tributaries are sampled. The hydraulic model computes the water levels along the river branches as a result of the upstream boundary condition and lateral inflows. At every time step, the model evaluates at each potential dike breach location whether the water level exceeds the dike breach threshold in terms of critical water level. If the critical water level is exceeded, the dike starts to breach based on the sampled dike breach formation time and final breach width. It is assumed that a dike breaches to the level of the natural terrain in case of failure (Dawson et al. 2005). An overview of the 


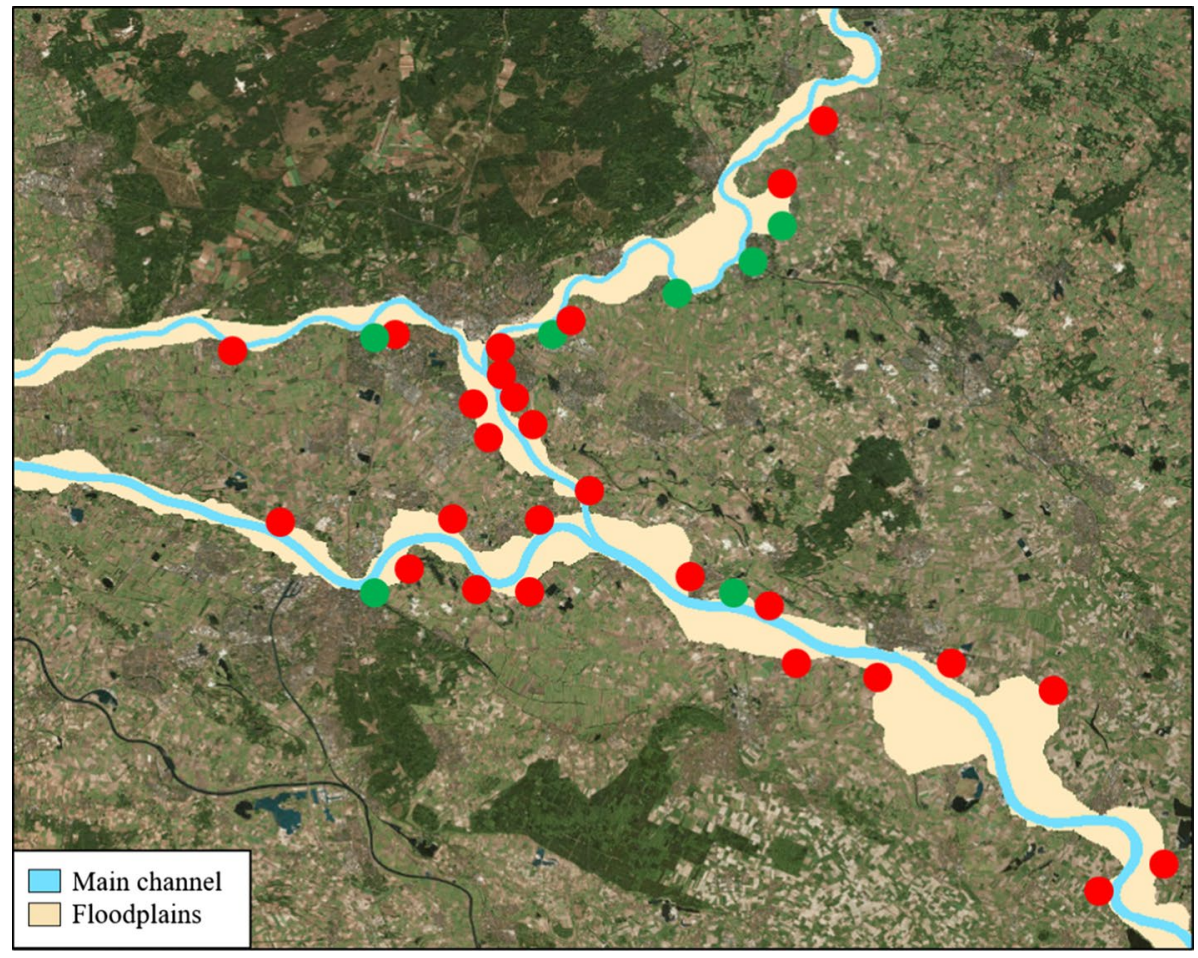

Fig. 4 Dike breach locations implemented in the model. These locations are based on a simulation run in which the embankments were removed from the geometry. The red bullets indicate the locations where water left the river system and the green bullets represent the locations where water re-entered the river system again

Monte Carlo analysis is given in Fig. 5. The next sections describe the five uncertain input parameters in more detail.

\subsection{Upstream hydrograph and hydrographs main tributaries}

For flood modelling, an upstream hydrograph is required as boundary condition. Sampling this hydrograph includes two steps, namely: sampling both a peak value and a discharge wave shape. A peak value between 12,000 and $23,500 \mathrm{~m}^{3} / \mathrm{s}$ is used such that a wide variety of potential flood scenarios is included in the analysis. This range is chosen since we are solely interested in the scenarios resulting in dike breaches and/or overflow causing overland flow patterns that have the potential to change downstream flood risk and the discharge partitioning of the Dutch Rhine river branches. Discharges smaller than $12,000 \mathrm{~m}^{3} / \mathrm{s}$ do not result in significant flooding upstream of Lobith as has been seen during the historical flood in 1995. Hence, a simulation with those discharges in which overflow and dike breaches are neglected provides similar results as a model run in which both overflow and dike breaches are possible to occur (Hegnauer et al. 2014). Therefore, only discharges larger than $12,000 \mathrm{~m}^{3} / \mathrm{s}$ are considered in the Monte Carlo analysis.

The upper bound of the discharge range has a value of $23,500 \mathrm{~m}^{3} / \mathrm{s}$. This rather high value is a result generated with GRADE (Generator of Rainfall and Discharge Extremes), 


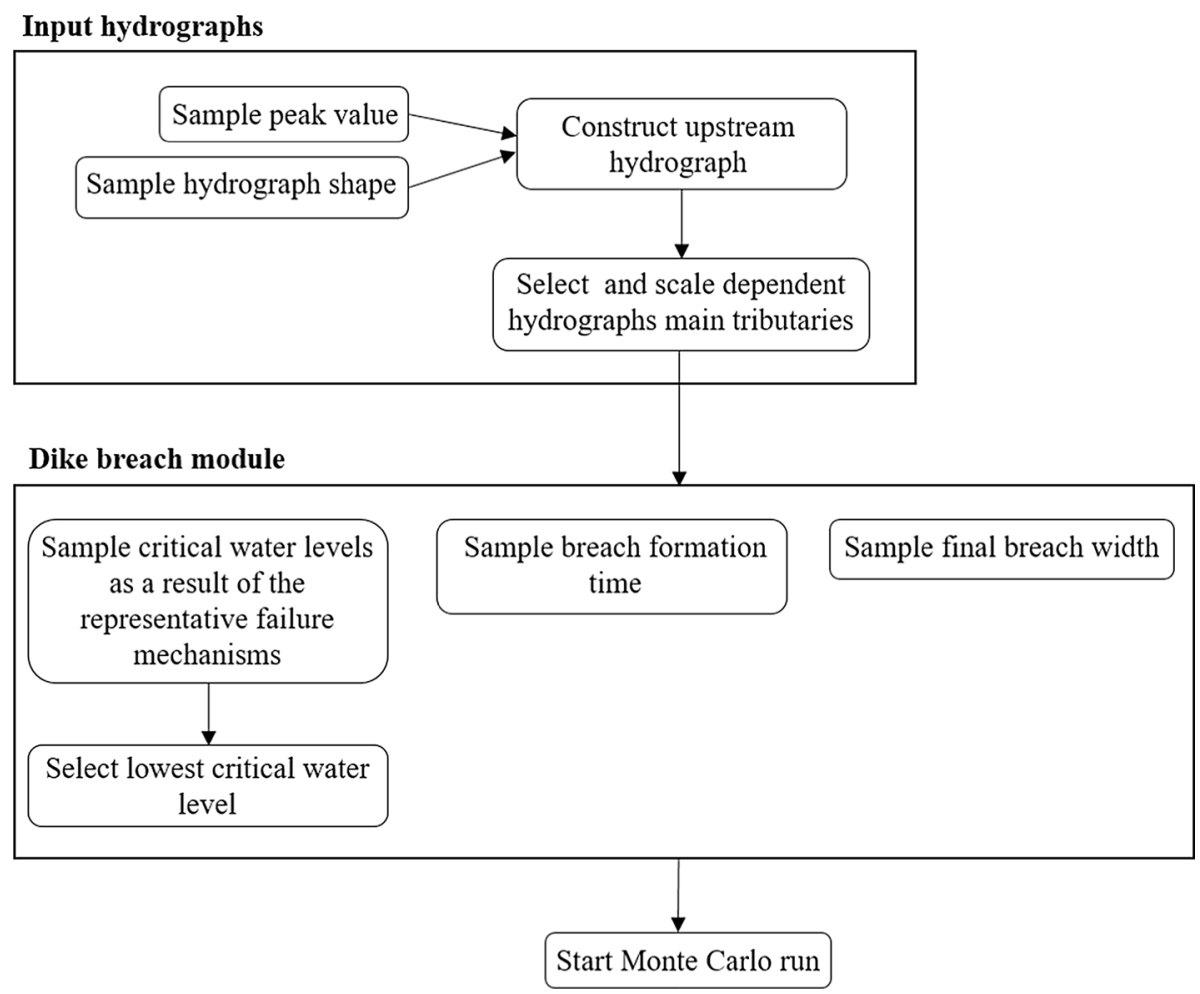

Fig. 5 Overview of the Monte Carlo sampling strategy

a new method to derive the design discharge for the Rhine and Meuse rivers in the Netherlands (Hegnauer et al. 2014). Under climate change conditions, this discharge corresponds with an expected return period of 30,000 years in 2085 (Hegnauer 2017) taking into account a rather wet climate change scenario in which an increase in temperature of $3.5^{\circ} \mathrm{C}$ and a high influence of changing air flow patterns is assumed (KNMI 2015). A return period of 30,000 years seems very high. However, for Dutch flood safety assessments, where a return period of 30,000 years is still within the safety standards considered in 2050, it is reasonable to use this large discharge at Andernach. Currently, the discharge corresponding to this return period at Andernach is equal to 17,110 $\mathrm{m}^{3} / \mathrm{s}$ (Hegnauer 2017).

Also the shape of the flood wave is based on GRADE. The GRADE data set consists of 50,000 years of discharge data based on re-sampled measured weather conditions (e.g. precipitation, temperature) and expected climate change conditions. Of this data set, peak discharges with a value larger than $12,000 \mathrm{~m}^{3} / \mathrm{s}$ at Andernach were identified. A 30-day time window was used in which the peak value occurs around day 20 such that the continuous data set of 50,000 years is divided into a set of potential upstream hydrographs (Fig. 6). Corresponding discharge waves of the Sieg, Ruhr and Lippe rivers were selected as well. Finally, the hydrographs are normalized such that the peak value is equal to 1.0 for rescaling purposes (Fig. 6). This method results in a data set of 276 potential upstream hydrograph shapes and corresponding hydrograph shapes of the main tributaries. For each Monte Carlo run, the selected upstream hydrograph is scaled such that the maximum 


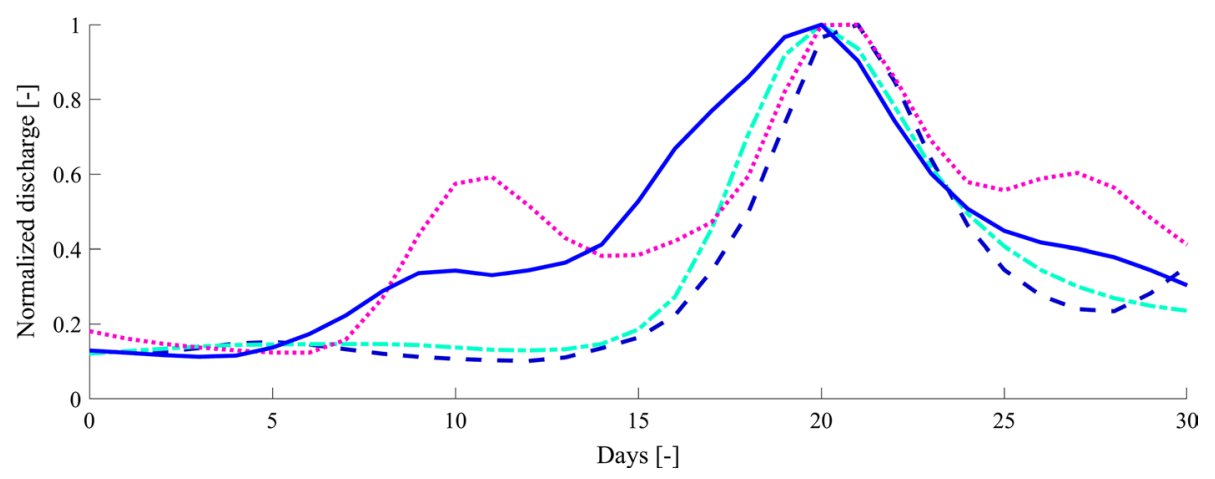

Fig. 6 Examples of normalized potential discharge wave shapes

discharge corresponds with the peak value sampled. In addition, corresponding discharge wave shapes of the tributaries are selected and scaled to the peak values sampled. Historic flood events have shown that there is a strong correlation between the maximum discharges of the main tributaries and of the maximum discharge along the Lower Rhine (Apel et al. 2009). Following the proposed method, the dependency of the hydrographs of the tributaries and Lower Rhine in terms of discharge wave shape and peak value is included in the analysis.

We chose to use the discharge wave shapes of the GRADE data set instead of measured discharge waves (as was done by Apel et al. (2004) and Vorogushyn et al. (2011)), since the GRADE data set includes a much larger variety of potential discharge wave shapes compared to the measured data set (e.g. a single sharp peak, a single broad peak or two peaks). Moreover, the GRADE data set has a larger spread of maximum values that are larger than $12,000 \mathrm{~m}^{3} / \mathrm{s}$ that may occur under current climate conditions (Fig. 6). The measured data set goes back to 1901, and only the three largest flood events (1926, 1993 and 1995) had maximum discharges near $12,000 \mathrm{~m}^{3} / \mathrm{s}$ (Hegnauer et al. 2014).

\subsection{Dike breach threshold}

Whether dike failure occurs can be computed using the equation $Z=R-L$ in which $Z<0$ represents failure, $R$ the strength of the dike structure and $L$ the hydraulic load. In this study, dike failure is assumed to be similar to a dike breach. The load is expressed as the water level during a flood event. For the Dutch dikes, the following four most dominant failure mechanisms are included in the analysis: wave overtopping, overflow, piping and macro-stability (Diermanse et al. 2015; De Bruijn et al. 2014). The normal distributions of the critical water levels of these four failure mechanisms are based on 1D fragility curves. Failure mechanisms wave overtopping and overflow are combined in a single fragility curve and referred to as wave overtopping from now on. The fragility curves used are based on the 2015 dike dimensions (van Vuren et al. 2017) and are provided by the Dutch Ministry of Infrastructure and Water Management. A 1D fragility curve expresses the reliability of a flood defence as a function of a defined dominant stress variable (Hall et al. 2003). The curves are 1D since they are a function of one variable, which in this case is the water level during the flood event. The use of fragility curves enables estimation of what failure mechanism will be dominant for a certain 
water level if multiple failure mechanisms are considered (Van der Meer et al. 2008). An example is given in Fig. 7a, in which the probability of failure is given as a function of the exceedance of a certain water level. This curve can be transformed into a normal distribution in which the probability of failure is given as a function of a specific water level (Fig. 7b). Using this principle, a dike may also breach during low flow although the probability of failure is relatively low. To exclude flood scenarios with an extremely low probability of occurrence from the analysis, we only focus on water levels within the $95 \%$ confidence interval (Fig. 7b).

The use of 1D fragility curves has the consequence that a dike breach always develops in the rising stage of the discharge wave. As a result, the dike breach has a relatively large influence on the resulting overland flow and maximum discharge further downstream. To overcome this problem, a time-dependent component can be included in the analysis such that a dike breach is triggered by a certain water level and a duration that this water level is exceeded (Currant et al. 2018). However, no 2D fragility curves (describing the probability as a function of water level and duration of exceedance) were available and hence it must be noted that the scenarios presented in this paper represent the most extreme situations.

For the German dikes, no 1D fragility curves for any of the failure mechanisms were available. Therefore, it is assumed that the Dutch 1D fragility curves of the part between the German-Dutch border and the first bifurcation point (where the Rhine river bifurcates into the Waal river and Pannerdensch Canal) for failure mechanism wave overtopping/overflow are representative for the dikes along the Lower Rhine downstream of the confluence with the Lippe river. Note that dike failure can already occur before the water level reached the dike crest caused by overflow. In reality, dikes can fail as a result of many failure mechanisms. However, it is assumed that only the failure probabilities caused by wave overtopping are significant and that hence the effects of other failure mechanisms can be neglected along the Lower Rhine. This assumption is in line with the work of Apel et al. (2009) and Prinsen et al. (2015). Apel et al. (2009) mention that the dikes along the Lower Rhine are well maintained and that the authorities responsible for dike safety state that the only mechanism influencing dike breaching along the
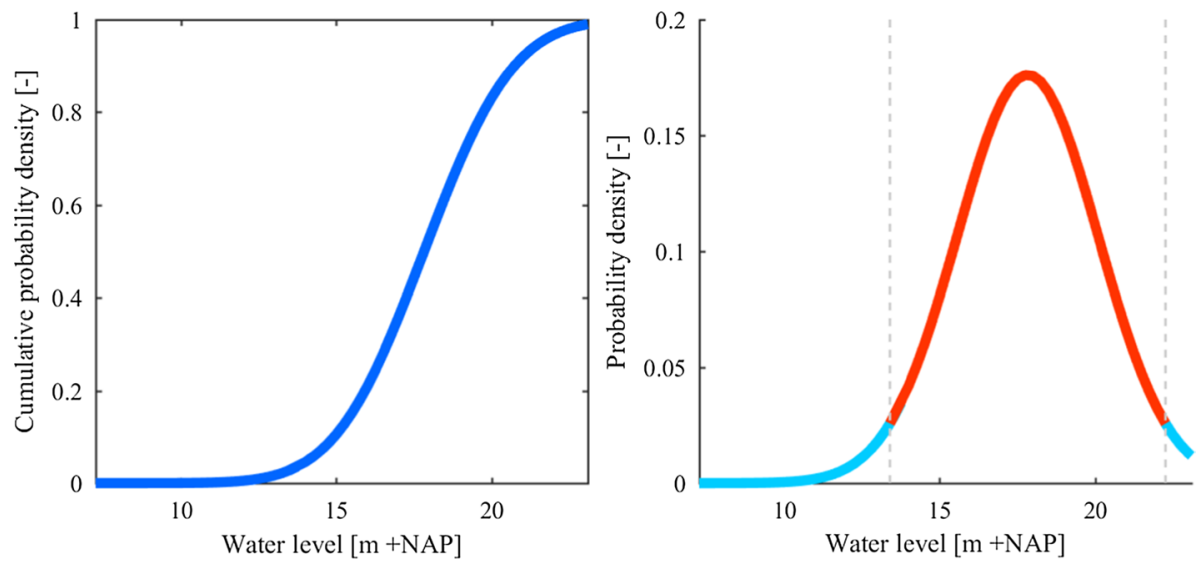

Fig. 7 Example of a fragility curve (left figure) and its normal distribution (right figure) in which the orange line indicates the $95 \%$ confidence interval 
Lower Rhine is overtopping. Furthermore, the proposed method is in line with the study of Lammersen and Hegnauer (2019) which also only includes the consequences of dike breaches caused by wave overtopping on downstream discharges.

Note that each potential dike breach location can fail caused by high water levels at the outer side (river system) and inner side (embanked areas) of the dike. However, no data about the strength of the dikes in case of hydraulic load on the inner side of the dike slope are available. It is assumed that the dikes in the study area are symmetric in shape and hence the fragility curves of the outer side of the dikes can be applied for the inner side as well. For each Monte Carlo simulation, critical water levels are sampled for each dike breach location. This results in three critical water levels for the Dutch dike breach locations as a result of failure mechanisms piping, wave overtopping and macro-stability, and in one critical water level for the German dike breach locations caused by wave overtopping. For the Dutch dike breach location, the lowest sampled critical water level is used as dike breach threshold in the simulation (Fig. 5).

\subsection{Dike breach formation time and final breach width}

The dike breach formation time represents the time until a breach has developed until its final width. Since there is not enough information available to quantify the relation between breach width, formation time and dike strength, the formation time and breach width are assumed as random variables. The distribution of the dike breach formation time is based on historical data. Data of Verheij and Van der Knaap (2003) are used resulting in a data set of 28 dike breaches with an average formation time of $13 \mathrm{~h}$ and a standard deviation of $17 \mathrm{~h}$. We assume a normal distribution since this distribution best represents the distribution of the data set. The normal distribution is bounded by a minimum formation time of 6 min and a maximum formation time of $50 \mathrm{~h}$, corresponding with the minimum and maximum values present in the data set.

Data of Apel et al. (2008) and data of Verheij and Van der Knaap (2003) are combined to determine the distribution of the final dike breach width, resulting in a data set of 46 dike breaches. The average dike breach width equals $75 \mathrm{~m}$ with a standard deviation of $55.5 \mathrm{~m}$. Again a normal distribution is assumed. The normal distribution is bounded by a minimum width of $3 \mathrm{~m}$ and a maximum width of $200 \mathrm{~m}$, representing the minimum and maximum values present in the data set. A maximum width of $200 \mathrm{~m}$ is also in line with the work of De Bruijn et al. (2014).

There are many parameters that may influence dike breach development (e.g. dike stability, failure mechanism, pace of rising and falling water level). For example, a rapid decline in water level will result faster in a stable dike breach width than a slowly decreasing water level (Verheij and Van der Knaap 2003). This explains the large range present in the data set. Since no information is available about the relation between all parameters that influence dike breach development, the full ranges (although relatively large) in formation time and final breach width present in the data sets are used in the analysis.

\subsection{Sampling strategy}

Most often a fully random Monte Carlo analysis is performed in which the uncertain input parameters are randomly sampled based on their distributions. This has as disadvantage that many runs are required to sufficiently capture the distributions of the input parameters. This is because it is likely that gaps or clusters are present in the sample when not enough 
samples are taken (Saltelli et al. 2008). Many sophisticated sampling techniques can be found in literature that attempt to reduce the amount of runs required, while the input space of the parameters is still sufficiently captured. Most commonly used sampling methods appear to be full factorial design, fractional factorial design, central composite design and Latin Hypercube sampling (LHS) (Razavi et al. 2012). The first three methods still require a relatively large number of simulations to generate all combinations to represent the corners of the input space if many uncertain input parameters are included in the analysis (Razavi et al. 2012; Saltelli et al. 2008). Contrarily, the LHS approach does not need extra simulation runs if more input parameters are included in the analysis (Razavi et al. 2012). Since the dike breach module (Fig. 5) includes many uncertain input parameters (water level threshold, final dike breach width and formation time for the 33 potential dike breach locations), LHS is used in which the distributions of the input parameters are divided into eight slices each having a probability of occurrence of $12.5 \%$. More information on how to set up an LHS can be found in Saltelli et al. (2008). For the input hydrograph shapes (Fig. 5), a random sampling technique is used, because the data set does not have a probability distribution as the previous mentioned input parameters. The data set consists of 276 different discharge wave shapes, each having equal probability of occurrence.

\section{Results: overland flow patterns and discharge partitioning}

During the Monte Carlo analysis, 227 runs were performed for a maximum upstream discharge ranging from 12,000 to $23,500 \mathrm{~m}^{3} / \mathrm{s}$. Using the method proposed by Apel et al. (2009) to study the effect of dike breaches on downstream discharges, we expect to find a significant reduction in the maximum discharge in downstream direction since overland flows and backwater effects were not included in their analysis.

Our results only focus on the areas downstream of the confluence with the Lippe river since solely flow patterns caused by dike breaches and overflow in this part of the model domain can change flood risk and discharge partitioning of the Rhine delta. We found that the maximum discharge at Andernach can be divided into three discharge ranges, each range having its own flood characteristics. These ranges are explained in more detail in the following sections.

\section{$5.1 Q_{\max }$ Andernach $<16,000 \mathrm{~m}^{3} / \mathrm{s}$}

It was found that up to a discharge wave with an upstream peak value of approximately $16,000 \mathrm{~m}^{3} / \mathrm{s}$, corresponding with a return period of approximately 7700 years under current climate conditions (Hegnauer 2017), overland flows have almost no influence on the downstream discharge partitioning. Overflow and/or dike breaches did occur resulting in inundation of the embanked area. However, because of the relatively low upstream maximum discharge, no significant flow patterns were found for most of the scenarios present in the Monte Carlo analysis. In general, the water that left the river system did not re-enter the river system again at a downstream location. Hence, only a reduction in the maximum downstream discharge was found (Fig. 8). For this situation, the results correspond to the results of Apel et al. (2009).

The most dominant flow patterns for an upstream maximum discharge smaller than $16,000 \mathrm{~m}^{3} / \mathrm{s}$ are presented in Fig. 9. These flow patterns are caused by dike breaches. Specifically, the Pannerdensch Canal is vulnerable to dike breaches resulting in overland flow 


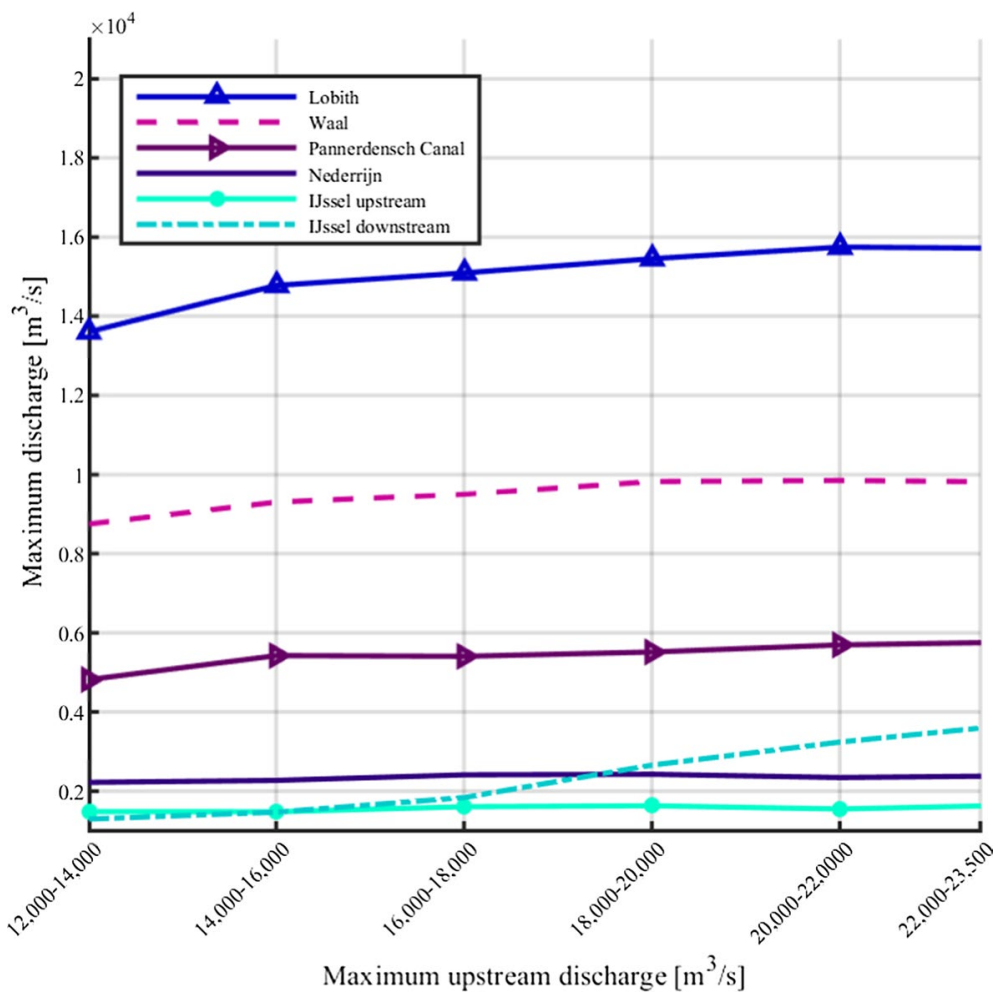

Fig. 8 Average maximum discharge per class at Lobith and along the Dutch Rhine river branches as a function of the maximum upstream discharge at Andernach. The blue star represents the maximum discharge at Lobith present in the MCA and has a value of $17,870 \mathrm{~m}^{3} / \mathrm{s}$

patterns 1 and 2. Flow pattern 2 first flows parallel to the IJssel river. Thereafter, its discharge starts to flow in two direction, where 2a continues to flow parallel to the river and $2 \mathrm{~b}$ starts to flow into the Old IJssel Valley. Furthermore, two dike breaches along the Waal and Nederrijn rivers result in inundations of the embanked areas and hence in a reduction in the maximum discharge further downstream (flow patterns 3 and 4 in Fig. 9).

We recall that for most scenarios with an upstream maximum discharge smaller than $16,000 \mathrm{~m}^{3} / \mathrm{s}$, the discharge that has left the river system as a result of dike breaches along the Dutch Rhine river branches did not flow back into the river system again at a more downstream location. However, still some severe flow patterns are possible to occur even though their probabilities are low. The Monte Carlo analysis showed that dike breaches along the Lower Rhine caused by wave overtopping are possible to occur if the discharge at Andernach is larger than $14,500 \mathrm{~m}^{3} / \mathrm{s}$, corresponding with a return period of approximately 1100 years under current climate conditions (Hegnauer 2017). For such a relatively low maximum upstream discharge, the water levels are still below the dike crest level along the Lower Rhine. The dike thus breaches as a result of wave overtopping. Although the probability of dike breaches is low for this upstream discharge, the effects are significant. A large amount of water starts to flow through the Old IJssel Valley (Flow pattern 5 in Fig. 10). Even for a discharge of approximately $14,500 \mathrm{~m}^{3} / \mathrm{s}$ at Andernach, the discharge through the Old IJssel Valley can be as large as $3400 \mathrm{~m}^{3} / \mathrm{s}$. This water mainly stays within 


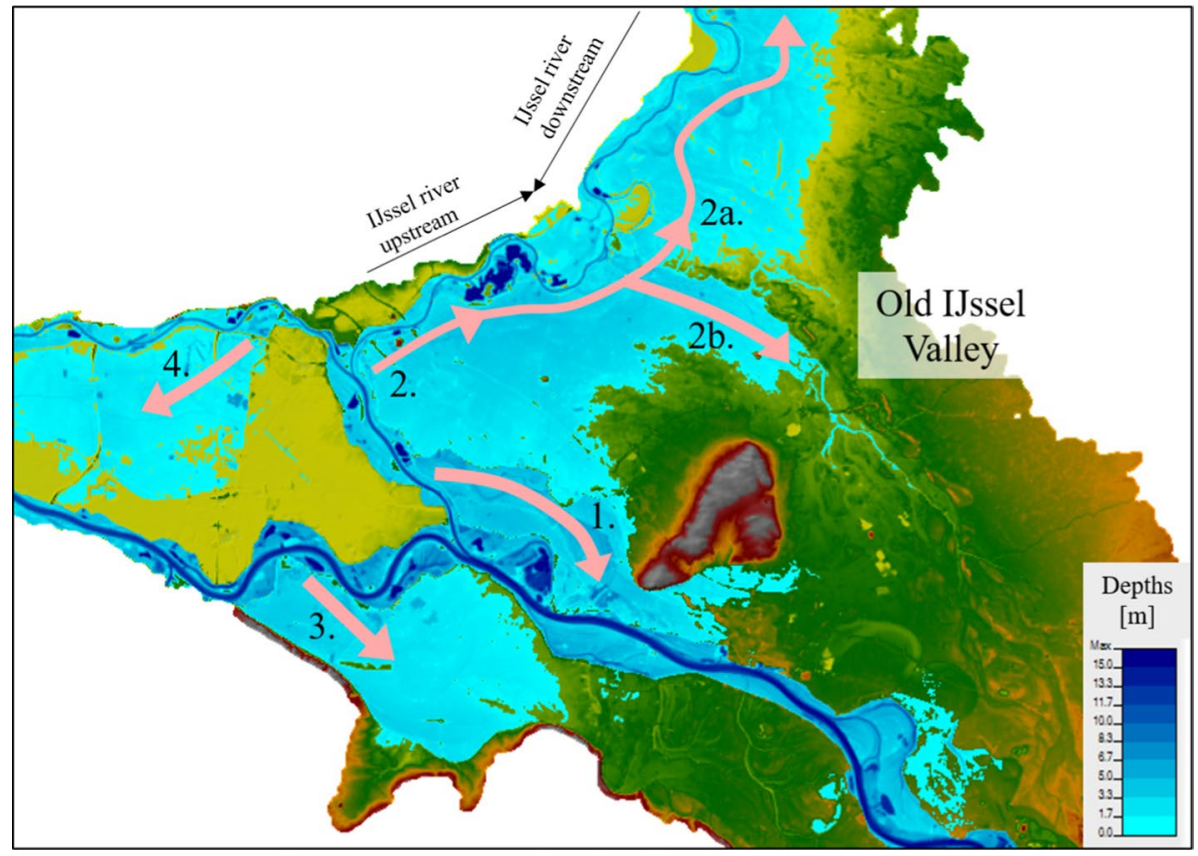

Fig. 9 The most dominant flow patterns if the maximum discharge at Andernach is smaller than $16,000 \mathrm{~m}^{3} / \mathrm{s}$. These flow patterns only result in a decrease in the maximum discharge further downstream

the embanked areas of the Old IJssel Valley. According to Mens et al. (2014), the worstcase discharge that can enter the IJssel river in the coming 50-100 years as a result of climate change is estimated at $3250 \mathrm{~m}^{3} / \mathrm{s}$. Hence, the inundations along the IJssel river caused by the overland flow through the Old IJssel Valley are much more severe than we would expect if this area can only be inundated as a result of dike breaches and overflow along the IJssel river itself. Therefore, it is highly important that such overland flow patterns are considered in flood safety assessments.

\section{$5.216,000 \mathrm{~m}^{3} / \mathrm{s}<Q_{\max }$ Andernach $<18,700 \mathrm{~m}^{3} / \mathrm{s}$}

For upstream discharge waves having a peak value larger than $16,000 \mathrm{~m}^{3} / \mathrm{s}$, dike breaches along the Lower Rhine start to occur more often as a result of higher water levels. The overland flow through the Old IJssel Valley with a discharge larger than $500 \mathrm{~m}^{3} / \mathrm{s}$ occurred in $44 \%$ of the cases for this specific upstream discharge range. The water that flows through the Old IJssel Valley starts to divide into two flow patterns when the water almost reaches the IJssel river. A part of the water flows into the IJssel river at the most upstream red box (Fig. 10) if the water level in the embanked areas exceeds the dike crest level. The remaining part starts to flow parallel to the IJssel river in downstream direction following flow pattern 2a. A part of this water may re-enter the IJssel river at the downstream red box (Fig. 10).

The water flowing through the Old IJssel Valley reaches the IJssel river later than the peak value of the discharge wave that flows through the IJssel river itself. This is because of the higher surface roughness in the embanked areas compared to the roughness of the 


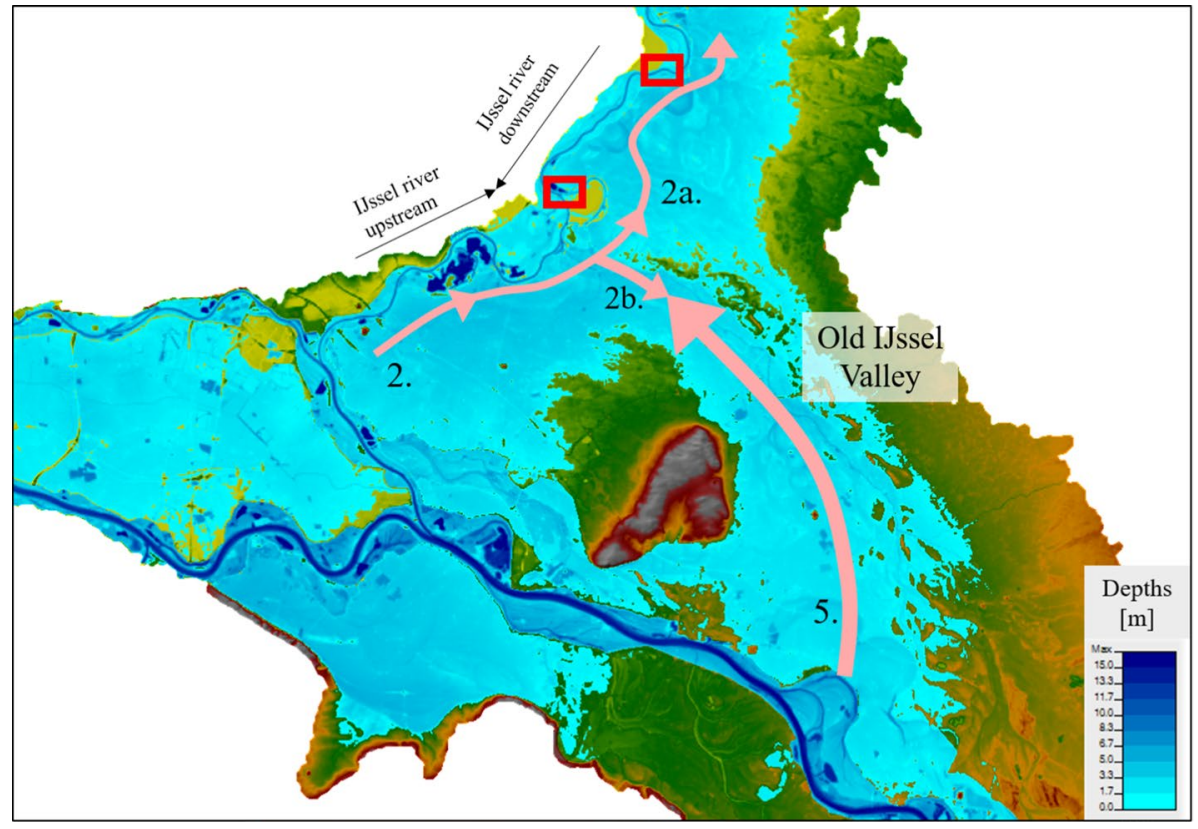

Fig. 10 The most dominant overland flow patterns if the discharge at Andernach is larger than $16,000 \mathrm{~m}^{3} / \mathrm{s}$. Flow pattern 5 can change the discharge partitioning along the Dutch Rhine river branches and flood risk, and can already occur if the maximum discharge at Andernach exceeds $14,500 \mathrm{~m}^{3} / \mathrm{s}$. The two red boxes indicate the locations along the IJssel river where overland flows may re-enter the river. The location where flow patterns $2 \mathrm{~b}$ and 5 coincide depends mostly on the maximum upstream discharge. The larger the maximum discharge at Andernach, the larger the flow through the Old IJssel Valley. Hence, the location where the two flows coincide is relatively close to the IJssel river. Contrarily, if the maximum discharge at Andernach is relatively low, the two flow patterns will coincide somewhere in the Old IJssel Valley further away from the IJssel river

main channel. Nevertheless, the discharge of the overland flow can be significantly larger than the discharge that enters the IJssel river through the river system. Hence, this overland flow pattern is capable of increasing the maximum discharge of the IJssel river during a flood event.

\section{$5.3 Q_{\max }$ Andernach $>18,700 \mathrm{~m}^{3} / \mathrm{s}$}

For upstream discharge waves having a peak value larger than approximately $18,700 \mathrm{~m}^{3} / \mathrm{s}$, the discharge along the downstream end of the IJssel river (near the downstream boundary) starts to increase significantly as a result of the overland flow through the Old IJssel Valley. This is caused by both the large overflow and the increase in dike breach probability along the Lower Rhine. Although the discharge capacity of the Old IJssel river itself is relatively small, the discharge through the entire valley can be much larger than this capacity. Consequently, the increased flood risk in the Old IJssel Valley caused by flow pattern 5 (Fig. 10) increases only further. For a maximum discharge larger than $18,700 \mathrm{~m}^{3} / \mathrm{s}$, the most downstream potential dike breach location along the IJssel river (Fig. 4) breached for $47 \%$ of the scenarios present 
in the Monte Carlo analysis. This breach was mostly caused by the high water levels in the embanked areas, resulting in an increase in the discharge at the IJssel river.

Although many overland flow patterns exist, only the flow through the Old IJssel Valley results in a change in downstream discharge partitioning and flood risk. Since the other river branches are not affected by overland flow patterns, the maximum potential discharge of these rivers converges towards a maximum value (Fig. 8). Only the maximum discharge at the downstream end of the IJssel river shows a strong positive correlation with the maximum discharge at Andernach. The flood defences along the IJssel river are not designed to withstand the large increase in maximum discharges at the downstream end of the IJssel river. Under normal conditions, we would expect that the discharge along the IJssel river is only as large as $50 \%$ of the discharge of the Nederrijn river. This discharge partitioning still holds for the upstream part of the IJssel river. Contrarily, for the downstream part of the IJssel river, a much larger discharge is found. Although a large flood event causing severe inundations is required to increase the discharge of the IJssel river as a result of overland flow patterns, this increased discharge may lead to even more inundations further downstream (located downstream of the model domain).

The dike breaches along the Lower Rhine result in a considerably reduction in the flood probability along the Waal river, the Pannerdensch Canal and the Nederrijn river. In the new risk-based approach (Sect. 2), the safety standards along these river branches will be much higher compared to the safety standards along the IJssel river. This is because a dike breach in the western part of the Netherlands has a much larger impact because of its higher population density, more vulnerable infrastructure and higher economic value compared to the eastern part of the Netherlands. It is expected that the consequences of a flood in the western part only increase further in the near future because people tend to move towards these areas because of their large economic value and job perspectives (Klijn et al. 2012). Therefore, the reduction in flood risk along the Waal river, Pannerdensch Canal and Nederrijn river as a result of upstream dike breaches may balance the increased flood risk along the downstream end of the IJssel river.

\subsection{Summary all discharges}

From the potential flood scenarios modelled, we find that the method proposed by Apel et al. (2009) can be applied to flood events that have a maximum upstream discharge lower than $16,000 \mathrm{~m}^{3} / \mathrm{s}$. For larger upstream flood events, significant overland flow patterns start to occur. This results in a change in flood risk and in an increase in the maximum discharge along the downstream end of the IJssel river. To correctly predict flood risk and the maximum discharge during extreme flood events for this river section, overland flows must be included in the analysis. This is because the method proposed by Apel et al. (2009) will underestimate the flood risk in the Old IJssel Valley and the maximum discharge along the downstream end of the IJssel river. For the other Rhine river branches, flood risk and the maximum discharge were not affected by overland flow patterns. However, backwater effects of dike breaches may still increase upstream discharges. Therefore, we conclude that it is of great importance to include overland flow patterns and backwater effects during flood modelling. 


\section{Sensitivity analysis}

\subsection{Quantitative results}

Section 5 shows that dike breaches affect downstream flood risk and the maximum discharge along certain river sections. Several uncertain input parameters were included in the analysis, raising the question of which parameter mostly influences the change in downstream discharge partitioning. Therefore, this section presents a brief sensitivity analysis to determine which potential flood scenario results in a major increase in the maximum discharge at the downstream end of the IJssel river and hence mostly changes the discharge partitioning along the Dutch Rhine river branches. The uncertain parameters in the Monte Carlo analysis that influence the discharge along the downstream end of the IJssel river and that are included in the sensitivity analysis are:

- Maximum upstream discharge

- Shape of the upstream hydrograph: a single peak or two peaks

- Number of dike breaches along the Lower Rhine (north side) which is a function of the sampled dike breach thresholds

- Average final width of the dike breaches along the Lower Rhine

- Average formation time of the dike breaches along the Lower Rhine

The purpose of the sensitivity analysis is screening of the most important input parameters, i.e. factor prioritization. If the number of simulations is much higher than the number of input parameters, multiple linear regression analysis can be highly effective in revealing the influence of each parameter (Saltelli et al. 2008). If the model does not contain any interactions between the input parameters (i.e. the model is additive), the linear regression function can be expressed as (Scheidt et al. 2018):

$$
y=\beta_{0}+\sum_{i=1}^{N} \beta_{i} x_{i}
$$

where $y$ represents the model output (in this study, the maximum discharge at the downstream end of the IJssel river) and $x_{i}$ the various input parameters. The coefficients $\beta_{0}$ and $\beta_{i}$ are determined by the least-square computation, based on the squared differences between the model output produced by the regression model and the actual model output produced by the hydraulic model (Saltelli et al. 2008). In the case of independent input parameters, the absolute standardized regression coefficient $\hat{\beta}_{i}$ can be used as a measure of sensitivity (Scheidt et al. 2018):

$$
\hat{\beta}_{i}=\left|\beta_{i} \frac{\sigma_{i}}{\sigma_{y}}\right|
$$

where $\hat{\beta}_{i}$ represents the standardized regression coefficient, and $\sigma_{i}$, and $\sigma_{y}$ represent the standard deviations for input parameter $x_{i}$ and the model output, respectively. In general, we state that the larger the computed value of $\hat{\beta}_{i}$ the larger the influence of the corresponding input parameter on the model output.

Table 3 shows the results of the multiple linear regression analysis. This clearly indicates that the maximum upstream discharge greatly influences the maximum discharge at 
Table 3 Results of the multiple linear regression analysis

\begin{tabular}{|c|c|c|}
\hline Input parameter & $\sigma_{i}$ & $\hat{\beta}_{i}$ \\
\hline Maximum discharge & $0.253290 .36\left(\mathrm{~m}^{3} / \mathrm{s}\right)$ & $5.63 \times 10^{-1}$ \\
\hline Shape hydrograph & $2.880 .39(-)$ & $1.07 \times 10^{-6}$ \\
\hline Nr. of dike breaches & $29.240 .59(-)$ & $2.53 \times 10^{-4}$ \\
\hline Average breach width & $4.6152 .08(\mathrm{~m})$ & $5.00 \times 10^{-2}$ \\
\hline Average formation time & $-3.4613 .40(\mathrm{~h})$ & $1.86 \times 10^{-3}$ \\
\hline
\end{tabular}

the downstream end of the IJssel river and thus the discharge partitioning because of its relatively large $\hat{\beta}_{i}$ value. The average breach width has the second highest $\hat{\beta}_{i}$ value. However, its value is more than one order of magnitude smaller than the value of the upstream maximum discharge. This indicates that only the latter significantly influences the change in flood risk in the Old IJssel Valley and the maximum discharge at the downstream end of the IJssel river. The influence of the remaining parameters is also relatively low compared to the maximum upstream discharge.

The number of dike breaches along the Lower Rhine, which is a function of the fragility curves used, has only a low influence on the overland flow patterns as a result of the great amount of overflow that occurs, specifically for the large upstream maximum discharges. Hence, the assumptions made about the German fragility curves only have a little effect on the large-scale flow patterns and hence flood risk.

\subsection{Qualitative results}

A drawback of the multiple linear regression analysis is that it depends on the degree of linearity of the model (Saltelli et al. 2008). A measure for linearity is expressed by $R^{2}$ (Saltelli et al. 2008):

$$
R^{2}=\sum_{i=1}^{N}\left(\hat{\beta}_{i}\right)^{2}
$$

where $R^{2}$ is also referred to as the model coefficient of determination and is equal to the fraction of the variance of the original data that is explained by the regression model. A value of $R^{2}$ equal to one means that the model is linear (Saltelli et al. 2008) and that the multiple linear regression model is capable of expressing all variance of the original data. The regression model applied in this study has a model coefficient of determination equal to 0.67 , indicating that only $67 \%$ of the variance of the original hydraulic model is explained by the regression model. However, the scatter plots and box plots in Figs. 11 and 12 confirm the results predicted by the multiple linear regression analysis. The scatter plots clearly show that there is a positive correlation between the maximum upstream discharge and the discharge at the downstream end of the IJssel river. As explained in Sect. 5, overflow and dike breaches along the Lower Rhine result in overland flow increasing the discharge of the IJssel river (Fig. 10). The discharge of this overland flow increases if the maximum upstream discharge increases. The random point cloud for the final breach width and formation time (Fig. 11) indicates that these parameters do not influence downstream maximum discharges, which is in line with the multiple linear regression analysis. Note that the points at which $\mathrm{x}=0$ in both scatter plots (final average breach width and average 

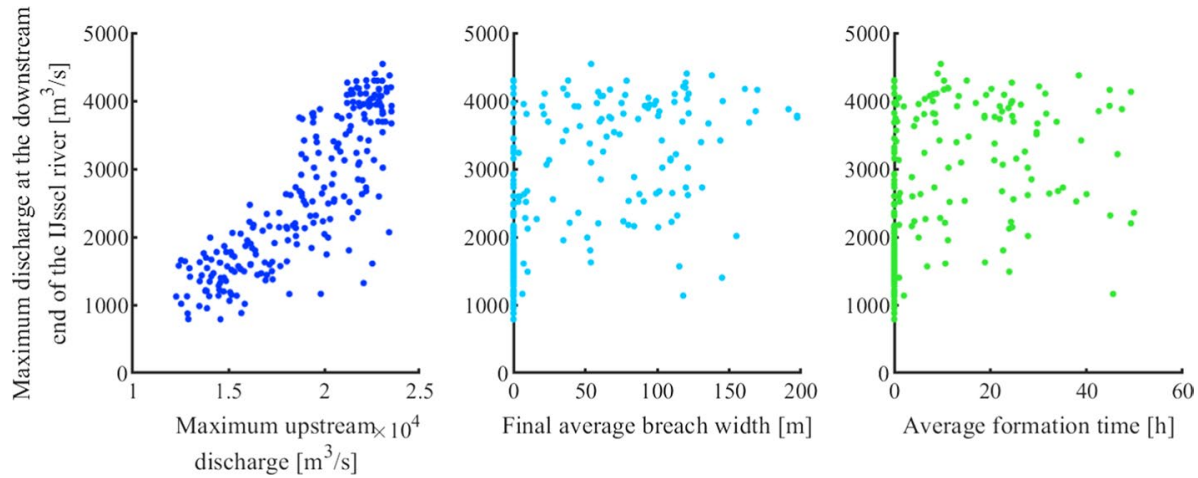

Fig. 11 Scatter plots which represent the correlation between the maximum upstream discharge, final breach width and formation time and the maximum discharge at the downstream end of the IJssel river
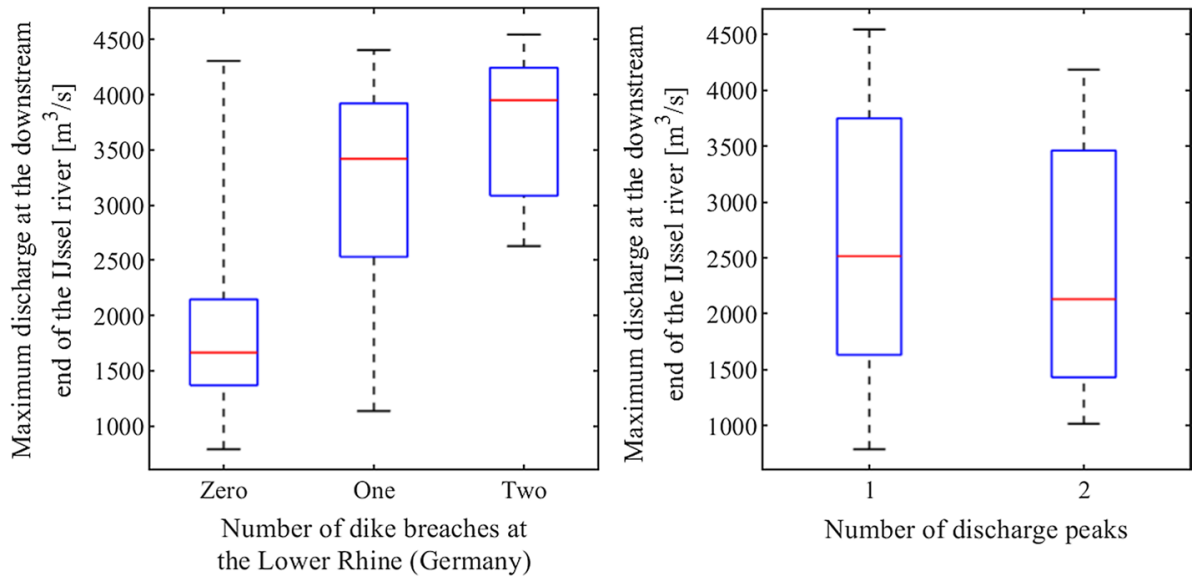

Fig. 12 Relation between the number of dike breaches along the Lower Rhine and resulting maximum discharge at the downstream end of the IJssel river (left figure) and the relation between discharge wave shape (a single peak or two peaks) and resulting maximum discharge at the downstream end of the IJssel river (right figure)

formation time) represent the scenarios in which no dike breaches occur along the Lower Rhine.

Figure 12 shows that the maximum discharge at the downstream end of the IJssel river increases with the number of dike breaches along the Lower Rhine, which is a function of the sampled dike breach thresholds. However, the box plot shows a wide spread represented by the blue boxes ( $50 \%$ confidence interval) indicating that the positive correlation is only weak. This agrees with the results of the multiple linear regression analysis in which the computed $\hat{\beta}_{i}$ value was low compared to that of the maximum upstream discharge. Moreover, Fig. 12 shows that there is no correlation between the shape of the upstream hydrograph and the maximum discharge at the downstream end of the IJssel river.

From the sensitivity analysis, we conclude that the breach characteristics in terms of breach development do not have a significant influence on predicted overland flows and 
hence downstream discharges, as was also found by Brunner (2014). Therefore, it can be stated that a sophisticated breach model is indeed not required for flood modelling purposes. Simplified assumptions as applied in this study can be used instead. More important for accurate prediction of potential flood scenarios are the upstream boundary conditions in terms of the maximum discharge.

\section{Discussion and conclusions}

We extended the method proposed by Apel et al. (2009) to study the effects of dike breaches and overflow on maximum discharges and flood risk in a bifurcating river system. A 1D-2D coupled model was developed that was able to predict water levels during flood events with high accuracy. The Rhine delta was used as a case study, but the proposed method can be applied to any river system if a high-resolution DEM is available. Applying this method will generate, amongst others, knowledge on the effect of dike breaches on the potential maximum discharges along various river branches.

The analysis has shown that dike breaches can change the maximum discharges of downstream rivers. However, this effect is not only beneficial in terms of a reduction in the maximum discharge further downstream, as was found by Apel et al. (2009). Large overland flows may change downstream discharge partitioning and flood risk. Furthermore, backwater effects may increase the maximum discharge upstream of a dike breach. For this specific case study, it was found that overflow and dike breaches along the Lower Rhine result in great inundations in the Old IJssel Valley. Although this overland flow pattern only occurs in very extreme cases, its effect on flood risk is relevant to consider. If the discharge of the overland flow through the Old IJssel Valley is extremely large, a part may enter the IJssel river. This consequently increases the maximum discharge at the downstream end of the IJssel river. In the most extreme scenario present in the Monte Carlo analysis, the maximum discharge at the downstream end of the IJssel river increased with $316 \%$. This increase is so severe, not only because of the large amount of water that is flowing through the Old IJssel Valley, but also because the discharge at the upstream part of the IJssel river, near the bifurcation point with the Nederrijn river, is relatively small. This is because only a small amount of water is flowing in the main channels as a result of the dike breaches along the Pannerdensch Canal and Lower Rhine. All other Rhine river branches were not affected by overland flow patterns. Hence, only a reduction in maximum discharge as a result of upstream dike breaches was found. Therefore, flood risk decreases along the Waal river, Pannerdensch Canal and Nederrijn river.

Overall, we conclude that dike breaches, resulting overland flow patterns and backwater effects must be included in the analysis of safety assessments since it may change downstream flood risk. This study shows that dike breaches may have a beneficial effect on some downstream river branches in terms of discharge reduction, while it may also cause severe problems along other river branches, especially if the discharge capacity of the specific river is relatively low compared to the discharge capacity of the other river branches. This is because an upstream dike breach and/or overflow can cause inundations that are much more severe than would be the case if only overflow and/or dike breaches occurs along the river with a relatively low discharge capacity.

Finally, the sensitivity analysis showed that a change in downstream discharge partitioning and flood risk is mostly influenced by the upstream maximum discharge, whereas 
breach characteristics (formation time and final breach width) do not have a significant impact on the predicted overland flow patterns.

Acknowledgements This research is supported by the Netherlands Organisation for Scientific Research (NWO, Project 14506) which is partly funded by the Ministry of Economic Affairs and Climate Policy. Furthermore, the research is supported by the Ministry of Infrastructure and Water Management and Deltares. This research has benefited from cooperation within the network of the Netherlands Centre for River Studies. The authors would like to thank the Dutch Ministry of Infrastructure and Water Management and the German Federal Institute of Hydrology for providing the data. Furthermore, the authors would like to thank Dr. Lammersen from the Dutch Ministry of Infrastructure and Water Management and Mrs. Becker from Deltares for their suggestions and valuable insights. In addition, the authors would like to thank Utrecht University for its cooperation in the NWO Project Floods of the past-Design for the future. Finally, the authors would like to thank the anonymous reviewers for their suggestions during the review process, which greatly improved the quality of the paper.

Open Access This article is distributed under the terms of the Creative Commons Attribution 4.0 International License (http://creativecommons.org/licenses/by/4.0/), which permits unrestricted use, distribution, and reproduction in any medium, provided you give appropriate credit to the original author(s) and the source, provide a link to the Creative Commons license, and indicate if changes were made.

\section{References}

Apel H, Merz B, Thieken AH (2008) Quantification of uncertainties in flood risk assessments. Int J River Basin Manag 6(2):149-162

Apel H, Merz B, Thieken AH (2009) Influence of dike breaches on flood frequency estimation. Comput Geosci 35(5):907-923

Apel H, Thieken AH, Merz B, Blöschl G (2004) Flood risk assessment and associated uncertainty. Nat Hazards Earth Syst Sci 4:295-308

Benito G, Lang M, Barriendos M, Llasat C, Francés F, Ouarda T, Thorndycraft V, Enzel Y, Bardossy A, Coeur D, Bobée B (2004) Use of systematic, palaeoflood and historical data for the improvement of flood risk estimation. Rev Sci Methods Nat Hazards 31:623-643

Bomers A, Hulscher SJMH, Lammersen R, Schielen RMJ (2018) The effect of dike breaches on downstream discharge partitioning near a river bifurcation. In Armanini A, Nucci E (eds) New challenges in hydraulic research and engineering: proceedings of the 5th IAHR Europe congress, pp 805-806, Trento, Italy

Bomers A, Schielen RMJ, Hulscher SJMH (2019a) Application of a lower-fidelity surrogate hydraulic model for historic flood reconstruction. Environ Model Softw 117:223-236

Bomers A, Schielen RMJ, Hulscher SJMH (2019b) The influence of grid shape and grid size on river modelling performance. Environ Fluid Mech. https://doi.org/10.1007/s10652-019-09670-4

Brunner GW (2014) Using HEC-RAS for Dam break studies, TD-39. Technical report August, US Army Corps of Engineers, Hydrologic Engineering Center (HEC), Davis, USA

Brunner GW (2016) HEC-RAS, River analysis system hydraulic reference manual, Version 5.0. Technical report February, US Army Corp of Engineers, Hydrologic Engineering Center (HEC), Davis, USA

Coleman JM, Roberts HH, Stone GW (1998) Mississippi River delta: an overview. J Coast Res 14(3):698-716

Currant A, De Bruijn KM, Kok M (2018) Influence of water level duration on dike breach triggering, focusing on system behaviour hazard analyses in lowland rivers. Georisk. https://doi.org/10.1080/17499 518.2018.1542498

Dawson R, Hall J, Sayers P, Bates P, Rosu C (2005) Sampling-based flood risk analysis for fluvial dike systems. Stoch Environ Res Risk Assess 19(6):388-402

De Bruijn KM, Diermanse FLM, Beckers JVL (2014) An advanced method for flood risk analysis in river deltas, applied to societal flood fatality risk in the Netherlands. Nat Hazards Earth Syst Sci 14:2767-2781

Diermanse FLM, De Bruijn KM, Beckers JVL, Kramer NL (2015) Importance sampling for efficient modelling of hydraulic loads in the Rhine-Meuse delta. Stoch Environ Res Risk Assess 29:637-652

Domeneghetti A, Vorogushyn S, Castellarin A, Merz B, Brath A (2013) Probabilistic flood hazard mapping: effects of uncertain boundary conditions. Hydrol Earth Syst Sci 17(8):3127-3140

Gee M (2010) Use of breach process models to estimate Hec-Ras dam breach parameters. In: Proceedings of the 2nd joint federal interagency conference, Las Vegas, USA

Hall JW, Dawson RJ, Sayers PB, Rosu C, Chatterton JB, Deakin R (2003) A methodology for national-scale flood risk assessment. Proc Inst Civil Eng Water Marit Eng 156(3):235-247 
Hegnauer M (2017) Analysis GRADE results for different locations in the Rhine Basin. Technical report, Deltares. Project 11200540-000-ZWS-0002, Delft, The Netherlands

Hegnauer M, Beersma JJ, van den Boogaard HFP, Buishand TA, Passchier RH (2014) Generator of rainfall and discharge extremes (GRADE) for the Rhine and Meuse basins. Final report of GRADE 2.0. Technical report, Deltares, Delft, The Netherlands

Hooijer A, Klijn F, Pedroli GBM, van Os AG (2004) Towards sustainable flood risk management in the Rhine and Meuse river basins: synopsis of the findings of IRMA-SPONGE. River Res Appl 20(3):343-357

ICPR (2001) Rhine-Atlas. Technical report, Internationale Kommission zum Schutz des Rhein, Koblenz, Germany

Klerk WJ, Kok M, De Bruijn KM, Jonkman SN, van Overloop PJATM (2014) Influence of load interdependencies of flood defences on probabilities and risks at the Bovenrijn/IJssel area, The Netherlands. In: 6th International conference on flood management, São Paulo, Brazil. Brazilian Water Resources Association and Acquacon Consultoria

Klijn F, De Bruijn KM, Knoop J, Kwadijk J (2012) Assessment of the Netherlands' flood risk management policy under global change. AMBIO 41(2):180-192

KNMI (2015) Brochure KNMI klimaatscenario's ’14, Herziene uitgave 2015. Technical report, Koninklijk Nederlands Meteorologisch Insituut, Ministry of Infrastructure and the Environment

Lammersen R, Hegnauer M (2019) Effect of upstream flooding on extreme discharge frequency estimations. In: Stouthamer E, Middelkoop H, Kleinhans M, van der Perk M, Straatsma M (eds) NCR days 2019: land of rivers, pp 14-15, Utrecht, The Netherlands. Netherlands Centre for River Studies publication 43-2019

Leandro J, Chen AS, Schumann A (2014) A 2D parallel diffusive wave model for floodplain inundation with variable time step (P-DWave). J Hydrol 517:250-259

Mens MJP, Klijn F, Schielen RMJ (2014) Enhancing flood risk system robustness in practice: insights from two river valleys. Int J River Basin Manag 13(3):297-304

Moussa R, Bocquillon C (2009) On the use of the diffusive wave for modelling extreme flood events with overbank flow in the floodplain. J Hydrol 374:116-135

Moya Quiroga V, Kure S, Udo K, Mano A (2016) Application of 2D numerical simulation for the analysis of the February 2014 Bolivian Amazonia flood: application of the new HEC-RAS version 5. RIBAGUA Rev Iberoam del Agua 3:25-33

Prinsen G, Van den Boogaard H, Hegnauer M (2015) Onzekerheidsanalyse hydraulica in GRADE. Technical report, Deltares, Delft, The Netherlands

Razavi S, Tolson BA, Burn DH (2012) Review of surrogate modeling in water resources. Water Resources Research 48(W07401):1-32

Saltelli A, Ratto M, Andres T, Campologno F, Cariboni J, Gatelli D, Saisana M, Tarantola S (2008) Global sensitivity analysis: the primer. Wiley, Hoboken

Scheidt C, Li L, Caers J (2018) Quantifying uncertainty in subsurface systems, geophysical monograph series, vol 236. Wiley, Hoboken

Schweckendiek T, Vrouwenvelder ACWM, van Mierlo MCLM, Calle EOF, Courage WMG (2008) River system behaviour effects on flood risk. In: Proceedings of the European safety and reliability conference, ESREL 2008, pp 1-8, Valencia, Spain

Spruyt A, Asselman N (2017) Afvoerverdeling rijntakken. Technical report, Deltares. Project 11200539-0000, Delft, The Netherlands

Tijssen A (2009) Herberekening werklijn Rijn in het kader van WTI2011. Technical report, Deltares, Delft, The Netherlands

Triet NVK, Dung NV, Fujii H, Kummu M, Merz B, Apel H (2017) Has dyke development in the Vietnamese Mekong Delta shifted flood hazard downstream? Hydrol Earth Syst Sci 21(8):3991-4010

Van Alphen J (2016) The delta programme and updated flood risk management policies in the Netherlands. J Flood Risk Manag 9(4):310-319

Van der Meer J, Ter Horst W, Van Velzen E (2008) Calculation of fragility curves for flood defence assets. Flood Risk Management: Research and Practice, pp 567-573

van Vuren S, Levelt O, Pol J, van der Meij R, de Grave P, Nugroho D, ter Horst W, Koopmans R, van der Scheer P, Asselman N, de Kruif A (2017) Beleidsstudie Kostenreductie Dijkversterking door Rivierverruiming. Toepassing methodiek op Rijntakken. Technical report, Consortium Deltares, HKV lijn in Water, Arcadis, Royal HaskoningDHV, Rijkswaterstaat

Verheij HJ, Van der Knaap FCM (2003) Modification breach growth model in HIS-OM. H.J. Verheij. Technical report, WL I Delft Hydraylics, Delft, The Netherlands

Vorogushyn S, Apel H, Merz B (2011) The impact of the uncertainty of dike breach development time on flood hazard. Phys Chem Earth 36:319-323

Vorogushyn S, Merz B, Lindenschmidt KE, Apel H (2010) A new methodology for flood hazard assessment considering dike breaches. Water Resour Res 46(8):1-17 
Publisher's Note Springer Nature remains neutral with regard to jurisdictional claims in published maps and institutional affiliations. 